\title{
Protein kinases modulate store-operated channels in pulmonary artery smooth muscle cells
}

\author{
I-Shan Chen ${ }^{1}$, Zen-Kong Dai ${ }^{2}$, Donald G Welsh ${ }^{3^{*}}$, Ing-Jun Chen ${ }^{1}$, Bin-Nan Wu ${ }^{1 *}$
}

\begin{abstract}
Background: This study investigates whether protein kinase G (PKG), protein kinase A (PKA) and protein kinase C (PKC) are involved in the regulatory mechanisms of store-operated channel (SOC) in pulmonary arteries.

Methods: Pulmonary artery smooth muscle cells (PASMCs) were enzymatically dissociated from rat intralobar pulmonary arteries. Whole cell, cell-attached and inside-out patch-clamp electrophysiology were used to monitor SOCs in isolated PASMCs.

Results: Initially the $\mathrm{Ca}^{2+}$-ATPase inhibitor cyclopiazonic acid (CPA, $\left.10 \mu \mathrm{M}\right)$ initiated a whole cell current that was reduced by the SOC blocker SKF-96365 $(10 \mu \mathrm{M})$. Subsequent work using both cell-attached and whole cell configurations revealed that the PKG and PKA inhibitors, KT5823 $(3 \mu \mathrm{M})$ and H-89 $(10 \mu \mathrm{M})$, also stimulated SOC activity; this augmentation was attenuated by the SOC blockers SKF-96365 $(10 \mu \mathrm{M})$ and $\mathrm{Ni}^{2+}(0.1 \mathrm{mM})$. Finally using the inside-out configuration, the PKC activator phorbol 12-myristate 13-acetate (PMA, $10 \mu \mathrm{M}$ ) was confirmed to modestly stimulate $\mathrm{SOC}$ activity although this augmentation appeared to be more substantial following the application of $10 \mu \mathrm{M}$ inositol 1,4,5-triphosphate $\left(\operatorname{Ins}(1,4,5) \mathrm{P}_{3}\right)$.
\end{abstract}

Conclusions: SOC activity in PASMCs was stimulated by the inhibition of PKG and PKA and the activation of PKC. Our findings suggest that the SOC could be a substrate of these protein kinases, which therefore would regulate the intracellular concentration of calcium and pulmonary arteriopathy via SOC.

\section{Background}

Intracellular calcium $\left(\left[\mathrm{Ca}^{2+}\right]_{\mathrm{i}}\right)$ is an important second messenger responsible for many physiological functions including contraction, cell growth and gene expression. Many agonists increase $\left[\mathrm{Ca}^{2+}\right]_{\mathrm{i}}$ by mobilizing intracellular $\mathrm{Ca}^{2+}$ stores, such as the sarcoplasmic (SR) or endoplasmic (ER) reticulum. To maintain $\mathrm{Ca}^{2+}$ signaling, these intracellular $\mathrm{Ca}^{2+}$ stores must be refilled and as such many agonists are thought to activate specialized plasma membrane channels termed store-operated channels (SOCs) [1]. By definition, SOCs are $\mathrm{Ca}^{2}$ ${ }^{+}$-permeable cation channels which are activated by depletion of intracellular $\mathrm{Ca}^{2+}$ stores [2]. The activation of SOCs is often termed 'capacitative $\mathrm{Ca}^{2+}$ entry (CCE)', as the principal function of these $\mathrm{Ca}^{2+}$ channels is to

\footnotetext{
* Correspondence: dwelsh@ucalgary.ca; binnan@kmu.edu.tw 'Department of Pharmacology, School of Medicine, College of Medicine, Kaohsiung Medical University, Kaohsiung, Taiwan

${ }^{3}$ Smooth Muscle Research Group and Department of Physiology and

Pharmacology, University of Calgary, Calgary, Alberta, Canada

Full list of author information is available at the end of the article
}

refill the internal stores, as if they were in essence capacitors [3]. Inhibitors of the sarco-endoplasmic reticulum $\mathrm{Ca}^{2+}$-ATPase pump (SERCA) are the most common tools used to deplete the intracellular $\mathrm{Ca}^{2+}$ stores and consequently activate these unique channels.

It is generally accepted that SOCs play an important role in regulating smooth muscle contraction and cellular proliferation in the resistance vasculature $[4,5]$. In a similar, although less documented manner, SOCs have also been coupled to the genesis of pulmonary vascular tone and pulmonary artery smooth muscle cell (PASMC) proliferation [6]. Given their functional importance and their role in severe pulmonary arteriopathies, there is considerable interest in defining how SOCs are regulated in PASMCs [7]. To date, literature specific to PASMCs has prominently stressed a role for $\mathrm{IP}_{3}, \mathrm{PIP}_{2}$ and other lipid products in the activation of these channels. While important, few pulmonary studies have ventured beyond these confines to electrically address other aspects of SOC regulation, including the role of protein kinase $\mathrm{G}$ (PKG), protein kinase A (PKA)

\section{() Biomed Central}

(c) 2011 Chen et al; licensee BioMed Central Ltd. This is an Open Access article distributed under the terms of the Creative Commons Attribution License (http://creativecommons.org/licenses/by/2.0), which permits unrestricted use, distribution, and reproduction in any medium, provided the original work is properly cited. 
and protein $\mathrm{C}(\mathrm{PKC})$. This is surprising given the rich nature of the research performed on smooth muscle cells derived from resistance arteries isolated from the coronary, mesenteric and hepatic circulation $[4,8,9]$.

The main objectives of this study were to isolate and characterize a SOC current in pulmonary artery myocytes and determine whether protein kinases (i.e. PKG, PKA and PKC) are involved in the activation of SOCs in PASMCs. Whole cell, cell-attached and inside out patch-clamp electrophysiology were used to monitor SOCs and the effects of various agents known to modulate protein kinases were recorded. Like smooth muscle cells isolated from the coronary, mesenteric and hepatic circulation, SOCs in PASMCs were stimulated by PKG and PKA inhibition and PKC activation. The functional significance of these findings is discussed.

\section{Materials and methods}

Animal procedures and tissue preparations

All procedures and protocols were approved by the Animal Care and Use Committee at Kaohsiung Medical University. Briefly, female Sprague-Dawley rats (250-350 g) were sacrificed with an overdose of urethane $(1.25 \mathrm{~g} /$ $\mathrm{kg}$ ) via intraperitoneal injection. Lungs were carefully removed and placed in cold phosphate-buffered saline containing (in mM): $122 \mathrm{NaCl}, 1 \mathrm{MgCl}_{2}, 0.5 \mathrm{KH}_{2} \mathrm{PO}_{4}$, 10 HEPES, $5 \mathrm{KCl}, 0.5 \mathrm{NaH}_{2} \mathrm{PO}_{4}, 11$ Glucose, 0.1 EGTA, $0.1 \mathrm{CaCl}_{2}$, with $\mathrm{pH}$ adjusted to 7.4 with $\mathrm{NaOH}$. Intralobar resistance pulmonary arteries (internal diameter $300-400 \mu \mathrm{m}$ ) were dissected free of the surrounding tissue and cut into $1 \mathrm{~mm}$ segments.

\section{Preparation of isolated pulmonary artery myocytes}

Pulmonary artery smooth muscle cells (PASMCs) from rat intralobar pulmonary arteries were enzymatically isolated as follows. Arterial segments were placed in a warm $\left(37^{\circ} \mathrm{C}\right)$ cell isolation medium containing (in $\mathrm{mM}$ ) $122 \mathrm{NaCl}, 1 \mathrm{MgCl}_{2}, 0.5 \mathrm{KH}_{2} \mathrm{PO}_{4}, 10$ HEPES, $5 \mathrm{KCl}, 0.5$ $\mathrm{NaH}_{2} \mathrm{PO}_{4}, 11$ Glucose, 0.1 EGTA ( $\mathrm{pH} 7.4, \mathrm{NaOH}$ ) for $20 \mathrm{~min}$. After this equilibration step, arterial segments were initially incubated $\left(37^{\circ} \mathrm{C}\right)$ in $1 \mathrm{mg} \mathrm{m}^{-1}$ papain and $0.85 \mathrm{mg} \mathrm{ml}^{-1}$ dithioerythritol for 20-25 min. After enzyme treatment, the tissue was washed three times in ice-cold isolation medium and triturated with a firepolished pipette to release the myocytes. Cells were stored in ice-cold isolation medium for use on the same day.

\section{Patch-clamp electrophysiology}

SOC currents in PASMCs were recorded in voltageclamp mode using whole cell, cell-attached and insideout configurations [10]. When employing whole cell patch-clamp electrophysiology, PASMCs were placed in a recording dish and perfused with a bath solution containing (in $\mathrm{mM}$ ): 120 sodium methanesulfonate, 20 $\mathrm{Ca}(\mathrm{OH})_{2}, 0.5$ 3,4-diaminopyridine, 10 HEPES and 10 glucose $(\mathrm{pH} 7.4, \mathrm{HCl})$. A recording electrode pulled from borosilicate glass (resistance, 4-7 $\mathrm{M} \Omega$ for whole cell recordings; 8-12 M $\Omega$ for cell-attached and insideout patches) was coated with sticky wax to reduce capacitance $[11,12]$ and backfilled with pipette solution containing (in $\mathrm{mM}$ ): $138 \mathrm{CsOH}, 2.5 \mathrm{EGTA}, 1 \mathrm{Ca}(\mathrm{OH})_{2}$ (free internal $\left[\mathrm{Ca}^{2+}\right] \sim 100 \mathrm{nM}$ as calculated using EQCAL software), 10 HEPES and $2 \mathrm{Na}_{2} \mathrm{ATP}(\mathrm{pH} 7.2, \mathrm{HCl})$. This pipette was gently lowered onto a PASMC, negative pressure was briefly applied to rupture the membrane and a gigaohm seal was obtained. Cells were voltage clamped at $0 \mathrm{mV}$ while resting membrane currents were recorded on an Axopatch 700A amplifier (Axon Instruments, Union City, CA, USA). Cells were subsequently equilibrated for $25 \mathrm{~min}$ and then exposed to a series of voltage ramps $\left(-100 \mathrm{mV}\right.$ to $\left.+100 \mathrm{mV}, 0.2 \mathrm{Vs}^{-1}\right)$ or step protocols $(20 \mathrm{mV}$ increments from -80 to $+20 \mathrm{mV}$ for $200 \mathrm{~ms}$ ). These voltage protocols were performed under resting conditions and in the presence of cyclopiazonic acid (CPA, $10 \mu \mathrm{M}) \pm 1$-[ $\beta$-(3-(4-Methoxyphenyl)propoxy)-4-methoxyphenethyl]-1H-imidazole $\mathrm{HCl}$ (SKF96365, $10 \mu \mathrm{M})[13,14],(9 \mathrm{~S}, 10 \mathrm{R}, 12 \mathrm{R})-2,3,9,10,11,12$-hexahydro-10-methoxy-2,9-dimethyl-1-oxo-9,12-epoxy-1Hdiindolo-[1,2,3-fg:30,20,10-kl]pyrrolo[3,4-i][1,6]benzodiazocine-10-carboxylic acid methylester (KT5823, $3 \mu \mathrm{M})$ or N-[2-((p-Bromocinnamyl)amino)ethyl]-5-isoquinolinesulfonamide $(\mathrm{H}-89,10 \mu \mathrm{M})$. Whole cell currents were then filtered at $1 \mathrm{kHz}$ (low-pass Bessel filter), digitized at $5 \mathrm{kHz}$ and stored on a computer for subsequent analysis with Clampfit 9.0. A $1 \mathrm{M} \mathrm{NaCl}$-agar salt bridge between the bath and the $\mathrm{Ag}-\mathrm{AgCl}$ reference electrode was used to minimize offset potentials [12,15]. All electrical recordings were performed at room temperature.

When using the inside-out and the cell-attached patch clamp configurations to monitor single channel activity, recording pipettes were backfilled with a solution containing (in $\mathrm{mM}$ ): $126 \mathrm{CsCl}, 10$ HEPES, 11 Glucose, 1.5 $\mathrm{CaCl}_{2}, 10$ TEA, 5 4-AP, 0.0002 Iberiotoxin, 0.1 DIDS, 0.1 Niflumic acid and 0.005 Nifedipine ( $\mathrm{pH} 7.2, \mathrm{NaOH})$. The bath solution for the inside-out configuration contained (in mM): $18 \mathrm{CsCl}, 108 \mathrm{C}_{2} \mathrm{H}_{3} \mathrm{CsO}_{2}, 1.2 \mathrm{MgCl}_{2}, 10$ HEPES, 11 Glucose, 1 BAPTA, $0.48 \mathrm{CaCl}_{2}, 1 \mathrm{Na}_{2}$ ATP and $0.2 \mathrm{NaGTP}$ ( $\mathrm{pH} 7.2$, Tris). The bath solution for the cell-attached configuration contained (in $\mathrm{mM}$ ): $126 \mathrm{KCl}$, $1.5 \mathrm{CaCl}_{2}, 10$ HEPES, 11 Glucose and 0.01 Nifedipine (pH 7.2, Tris). Following a 25 min equilibration period, single channel activity in excised patches was recorded at $-80 \mathrm{mV}$, filtered at $100 \mathrm{~Hz}$ and digitized at $50 \mathrm{kHz}$. These recordings were collected under resting conditions and in the presence of phorbol 12-myristate 13acetate (PMA, $10 \mu \mathrm{M}$ ), inositol-1,4,5-triphosphate (Ins $\left.(1,4,5) \mathrm{P}_{3}, 10 \mu \mathrm{M}\right)$, KT5823 $(3 \mu \mathrm{M})$ and $\mathrm{H}-89(10 \mu \mathrm{M})$. 


\section{Data analysis and statistics}

Whole cell SOC currents were analyzed from the baseline-to-peak amplitude within $50 \mathrm{~ms}$. Single SOC current amplitudes were calculated from idealized traces of at least $60 \mathrm{~s}$ in duration using the $50 \%$ threshold method and analyzed using Clampfit 9.0 as previously described [8]. For single channel analysis, SOC activity $\left(\mathrm{NP}_{\mathrm{o}}\right)$ was determined from continuous gap-free data using Clampfit 9.0. The $\mathrm{NP}_{\mathrm{o}}$ was calculated from the following equation: $\mathrm{NP}_{\mathrm{o}}=\left(\Sigma t_{i} i\right) / \mathrm{T}$, where $i$ is the number of channels open, $t_{i}$ is the open time for each level $i$ and $\mathrm{T}$ is the total time of analysis. Data are expressed as means $\pm \mathrm{SE}, n$ indicating the number of cells. Repeated measures analysis of variance (ANOVA) compared values at a given voltage. When appropriate, a Tukey-Kramer pairwise comparison was used for post hoc analysis. ANOVA followed by Dunnett's test was performed to statistically compare the open probability of SOCs. $P \leq 0.05$ was considered statistically significant.

\section{Chemicals}

Buffer reagents, papain, dithioerythritol, H-89, KT5823, PMA, CPA, Ins $(1,4,5) \mathrm{P}_{3}, \mathrm{NiCl}_{2}$ and SKF-96365 were obtained from Sigma-Aldrich Chemical Co. (St Louis, MO, USA). All drugs and reagents were dissolved in distilled water unless otherwise noted. CPA, PMA and KT5823 were dissolved in dimethylsulphoxide at 10 $\mathrm{mM}$. Serial dilutions were made in phosphate-buffered solution to a final solvent concentration of $\leq 0.01 \%$.

\section{Results}

\section{CPA evoked whole cell currents in rat PASMCs}

Our investigation of SOCs in PASMCs first began by monitoring the whole cell currents evoked by CPA. This assessment involved the application of voltage ramps $\left(-100 \mathrm{mV}\right.$ to $\left.+100 \mathrm{mV}, 0.2 \mathrm{Vs}^{-1}\right)$ every $30 \mathrm{~s}$ from a holding potential of $0 \mathrm{mV}$ in order to inactivate voltage-dependent $\mathrm{Na}^{+}$and $\mathrm{Ca}^{2+}$ channels. The recording solutions dictate that inward currents at negative potentials should be the result of $\mathrm{Ca}^{2+}$ and $\mathrm{Na}^{+}$influx, while outward current at positive potentials should be putatively generated by $\mathrm{Cs}^{+}$efflux [13]. Figure 1 illustrates that bath application of $10 \mu \mathrm{M}$ CPA induces a whole cell SOC current that displays modest outward rectification and which reverses at $-2 \pm 1 \mathrm{mV}(\mathrm{n}=6)$. In the presence of CPA, current density at $-100 \mathrm{mV}$ and +100 $\mathrm{mV}$ peaked at $-7.3 \pm 1.1 \mathrm{pA} \mathrm{pF}^{-1}$ and $13.9 \pm 1.1 \mathrm{pA} \mathrm{pF}^{-}$ ${ }^{1}(\mathrm{n}=6)$, respectively. These values were significantly greater $(\mathrm{P}<0.01)$ than control $\left(-1.6 \pm 0.1 \mathrm{pA} \mathrm{pF}^{-1}\right.$ and $3.5 \pm 0.3 \mathrm{pA} \mathrm{pF}^{-1}$ at $-100 \mathrm{mV}$ and $+100 \mathrm{mV}$, respectively). CPA evoked whole cell currents were subsequently attenuated by the addition of SKF-96365 (10 $\mu \mathrm{M}$, a SOC inhibitor) to the perfusate. In the presence of CPA and SKF-96365, current density at $-100 \mathrm{mV}$ and $+100 \mathrm{mV}$ was $4.6 \pm 0.8 \mathrm{pA} \mathrm{pF}^{-1}$ and $6.5 \pm 1.1 \mathrm{pA} \mathrm{pF}^{-1}$, respectively.

\section{Activation of SOCs by a PKG inhibitor}

To determine whether PKG can modulate SOCs, this study first employed whole cell patch clamp electrophysiology to monitor SOC currents in the absence of presence of KT5823. The representative trace in Figure 2A illustrates that the bath application of KT5823 (3 $\mu \mathrm{M})$ elevated SOC current and that SOC inhibitors SKF$96365(10 \mu \mathrm{M})$ and $\mathrm{Ni}^{2+}(0.1 \mathrm{mM})[13,16]$ reversed and attenuated this effect respectively. As shown in Figure $2 \mathrm{~B}$, the mean inward current (at $-80 \mathrm{mV}$ ) increased from $-21.6 \pm 1.4 \mathrm{pA}$ to $-138.8 \pm 12.0 \mathrm{pA}(\mathrm{n}=6, \mathrm{P}<$ 0.01 ) in the presence of KT5823 and this effect was largely eliminated by SKF-96365 $(-23.5 \pm 2.1 \mathrm{pA}, \mathrm{n}=6, \mathrm{P}$ $<0.01)$ or $\mathrm{Ni}^{2+}(-82.0 \pm 10.1 \mathrm{pA}, \mathrm{n}=6, \mathrm{P}<0.01)$. With whole cell measurements suggesting that PKG likely inhibits SOCs in PASMCs, the cell-attached configuration was subsequently employed to assess single channel SOC activity prior to and following PKG inhibition. Representative traces in Figure 3A show on two different time scales that the bath application of KT5823 (3 $\mu \mathrm{M})$ increases SOC activity. Summary data in Figure 3B highlights that KT5823 elevated the mean open probability $\left(\mathrm{NP}_{\mathrm{o}}\right)$ from $0.0107 \pm 0.0059$ to $0.0589 \pm 0.0063$ (n $=6, \mathrm{P}<0.01)$.

\section{Activation of SOCs by a PKA inhibitor}

To ascertain the role of PKA in the modulation of SOCs, this study again employed whole cell patch clamp electrophysiology to monitor SOC currents in the absence and presence of $\mathrm{H}-89$. The representative trace in Figure 4A shows that the addition of H-89 (10 $\mu \mathrm{M})$ significantly increased the SOC current and that the bath application of SKF-96365 $(10 \mu \mathrm{M})$ and $\mathrm{Ni}^{2+}$ (0.1 $\mathrm{mM})$ abolished and attenuated this elevation respectively. Mean inward current (at $-80 \mathrm{mV}$ ) plotted in Figure $4 \mathrm{~B}$ further emphasized that the H-89 induced increase in SOC activity $(-16.2 \pm 0.5 \mathrm{pA}$ to $-98.8 \pm 9.1$ $\mathrm{pA}, \mathrm{n}=6, \mathrm{P}<0.01)$ was indeed effectively blocked by SKF-96365 (-17.5 $\pm 1.6 \mathrm{pA}, \mathrm{n}=6, \mathrm{P}<0.01)$ or $\mathrm{Ni}^{2+}$ $(-59.4 \pm 9.5 \mathrm{pA}, \mathrm{n}=6, \mathrm{P}<0.01)$. With whole cell measurements indicating that PKA likely inhibits SOCs in PASMCs, the cell-attached configuration was once again employed to monitor single channel SOC activity. The representative trace in Figure 5A nicely illustrates, at two different time scales, that the bath application of H-89 (10 $\mu \mathrm{M})$ elevates SOC activity. Mean $\mathrm{NP}_{\mathrm{o}}$ was plotted in Figure $5 \mathrm{~B}$ and reinforces that single channel SOC activity rose from $0.0106 \pm 0.0056$ to $0.0798 \pm 0.0028(\mathrm{n}=6, \mathrm{P}<0.01)$ in the presence of $\mathrm{H}-89$. 


\section{A}

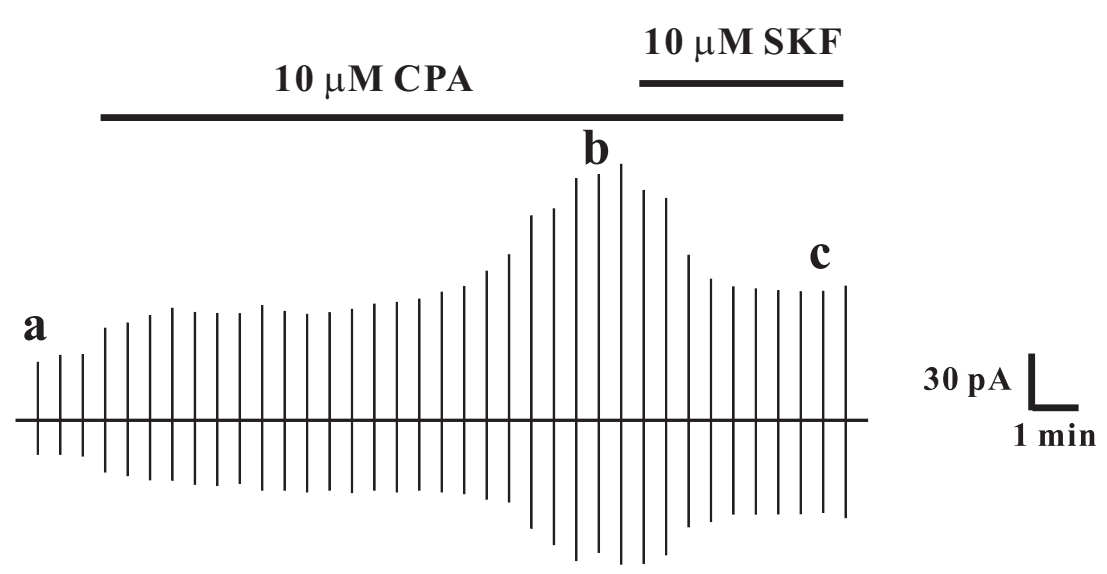

B

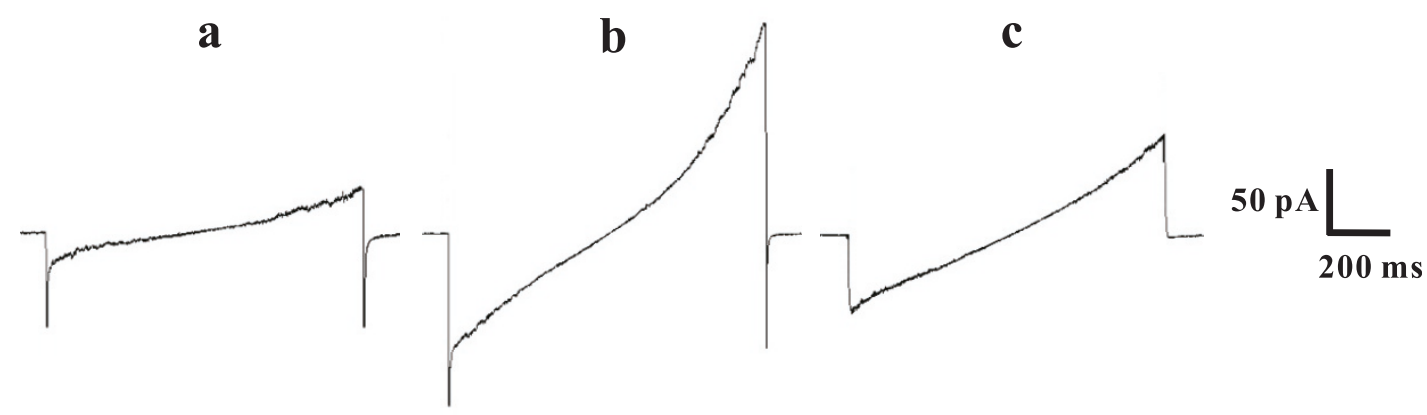

C

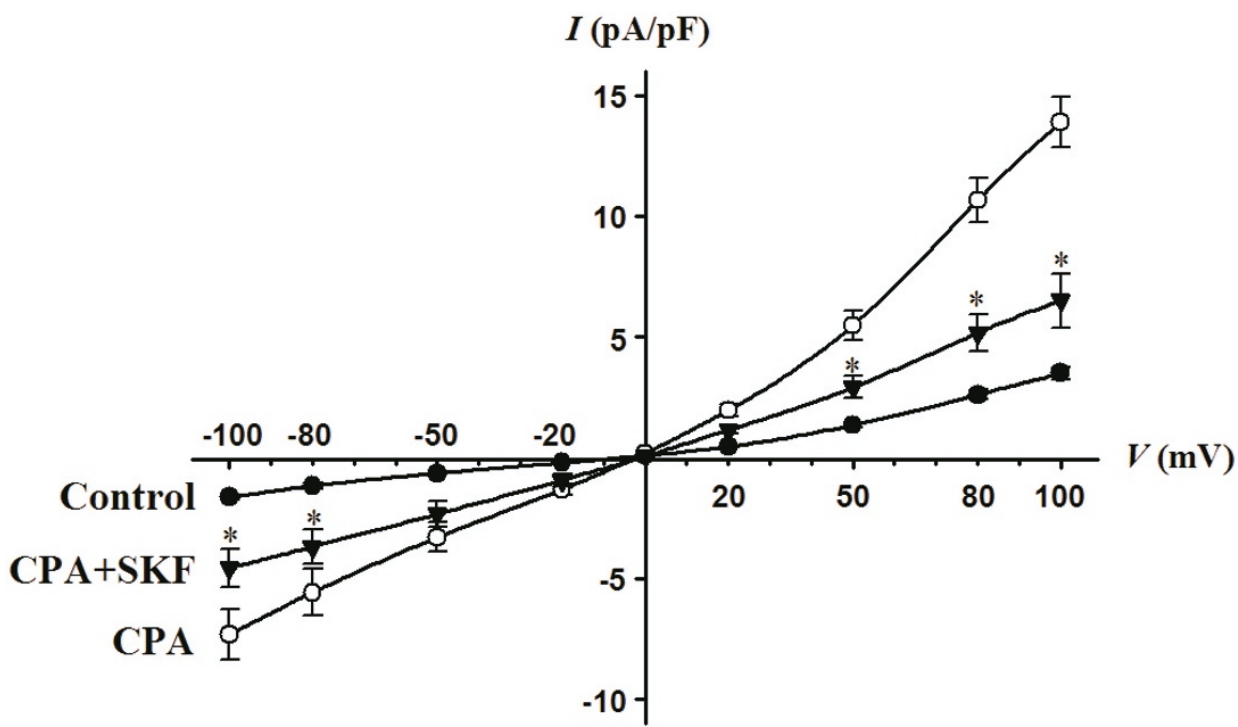

Figure 1 Cyclopiazonic acid (CPA) evokes an SOC conductance. Using whole cell patch clamp electrophysiology, PASMCs were voltage clamped and then periodically exposed to voltage ramps $(-100 \mathrm{mV}$ to $+100 \mathrm{mV})$ in the absence and presence of $10 \mu \mathrm{M} C P A \pm 10 \mu \mathrm{M}$ SKF96365 (SKF). A, original traces showing that CPA activates whole cell SOC currents in PASMCs. SKF-96365 was added to the perfusate 12 min after CPA. B, individual I-V relationships under resting conditions (a, Control), and in the presence of CPA (b) and SKF-96365 (c). C, mean I-V relationships of whole cell SOC currents. Data are means $\pm S E, n=6 .{ }^{*}$ denotes significant difference CPA alone. 
A

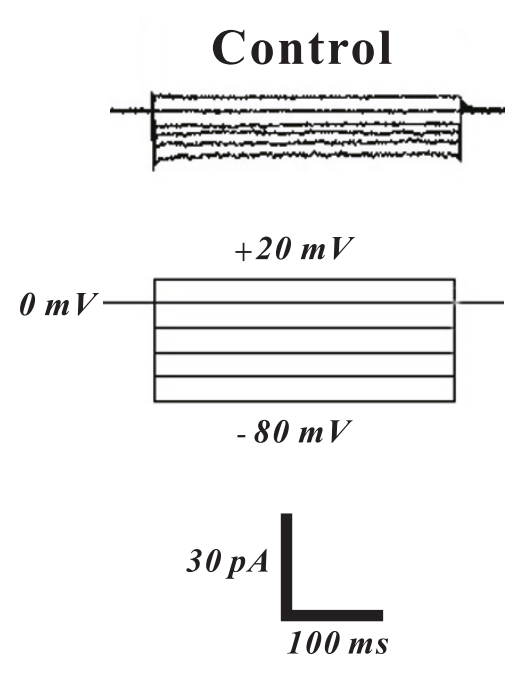

B

\section{KT 5823}
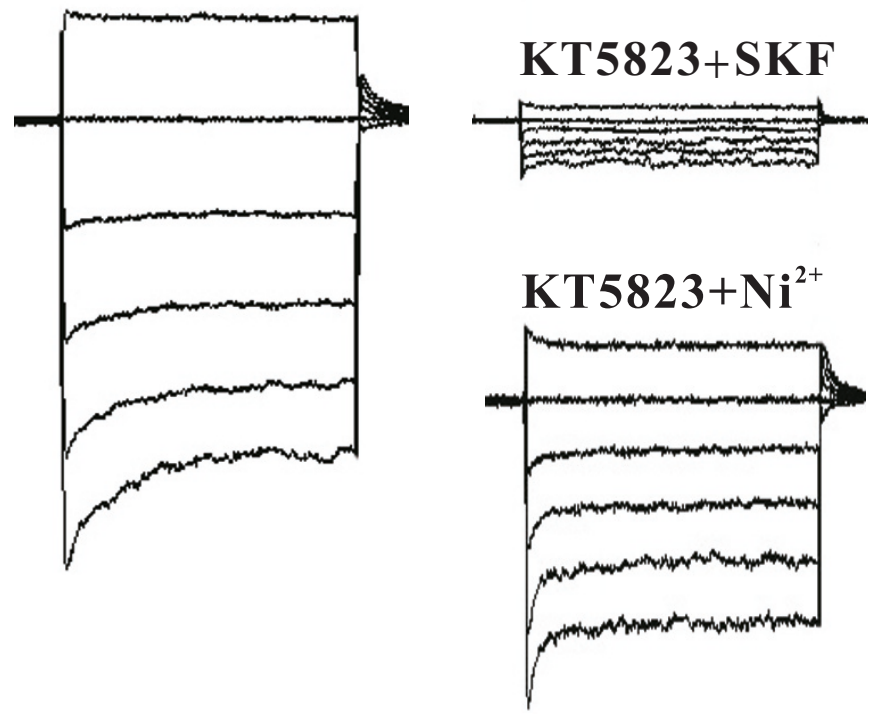

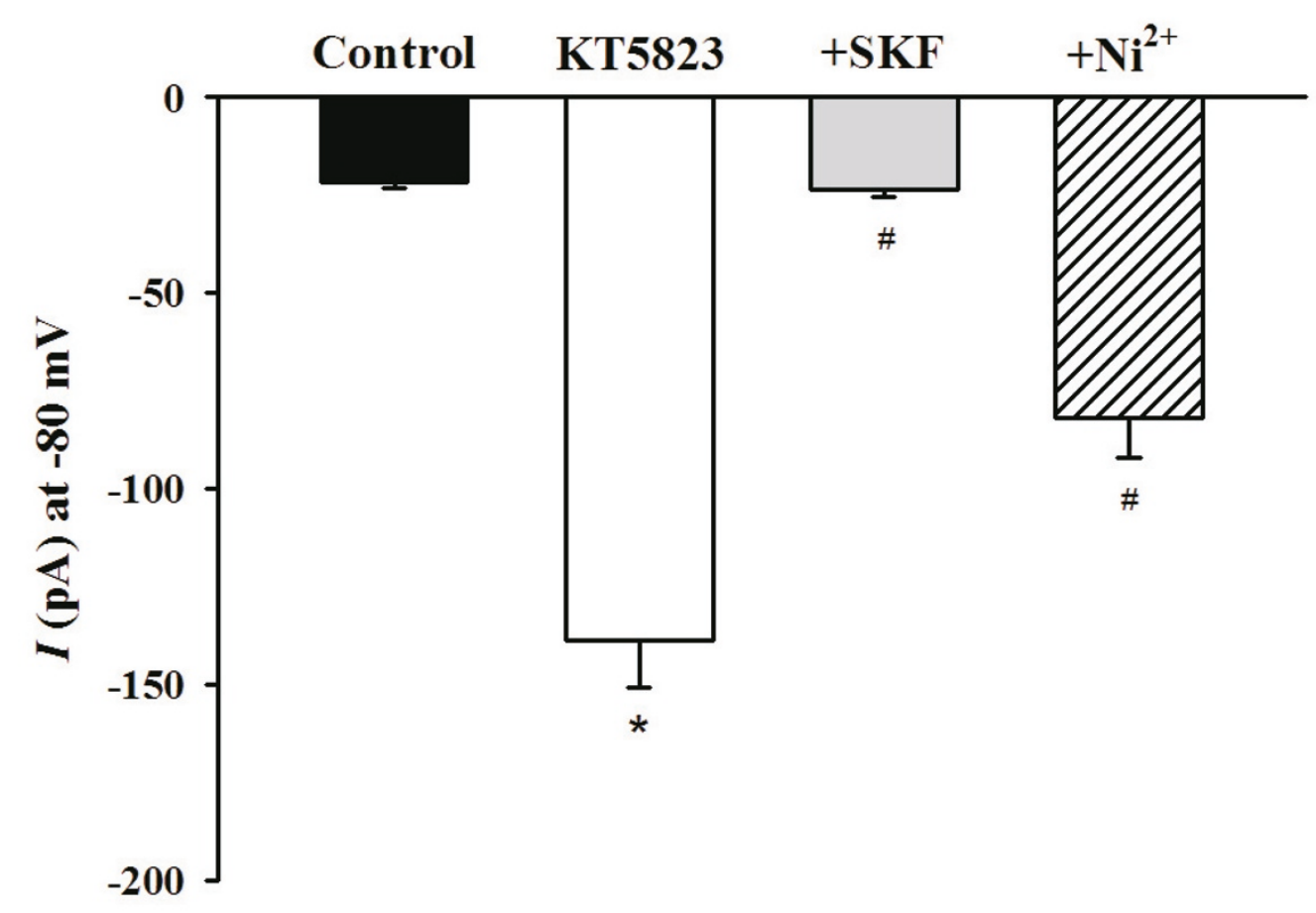

Figure 2 PKG inhibition by KT5823 augments SOC whole cell currents. Using whole cell patch clamp electrophysiology, PASMCs were voltage clamped and then periodically exposed to a step protocol (-80 mV to $+20 \mathrm{mV}, 20 \mathrm{mV}$ increments, $300 \mathrm{~ms}$ duration) in the absence and

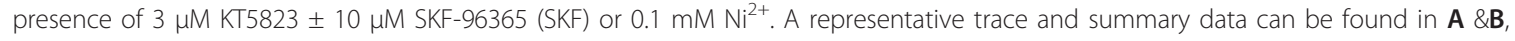
respectively. Data are means $\pm S E, n=6 .{ }^{*}$ and \# denote significant difference from control and KT5832, respectively. 


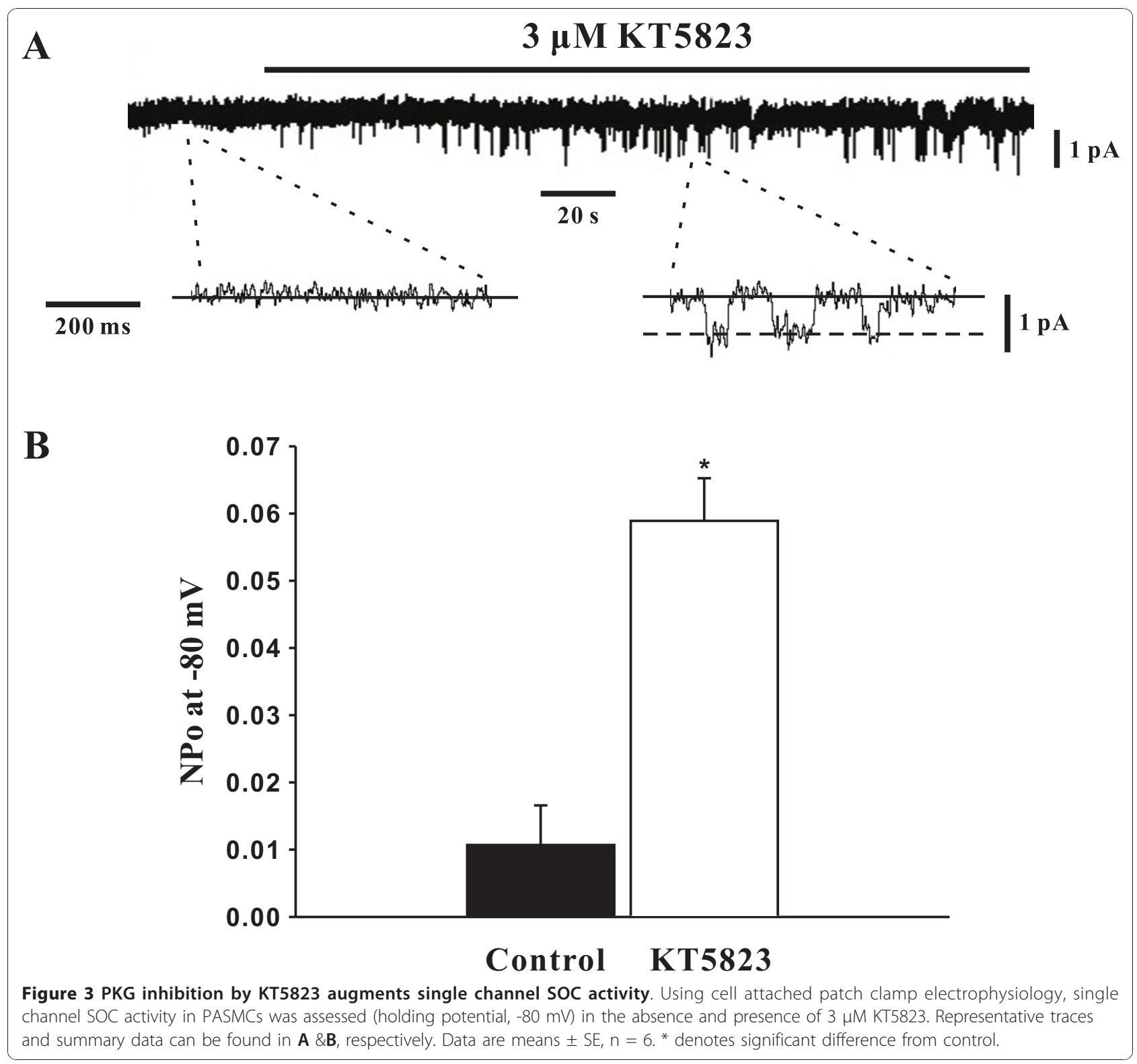

\section{Activation of SOCs by a PKC activator and $\mathrm{IP}_{3}$}

Finally, to study the involvement of PKC and possibly Ins $(1,4,5) \mathrm{P}_{3}$ in SOC modulation, the inside-out configuration was utilized to monitor these channels in the absence and presence of PMA (a PKC activator) and Ins $(1,4,5) \mathrm{P}_{3}$. As the representative traces in Figure 6A show, bath application of PMA $(10 \mu \mathrm{M})$ induced a modest increase in SOC activity that was further augmented by the addition of $\operatorname{Ins}(1,4,5) \mathrm{P}_{3}$. The amplitude and $\mathrm{NP}_{\mathrm{o}}$ histograms in Figure $6 \mathrm{~B}$ and $6 \mathrm{C}$ statistical confirm this. Of particular note was the increase in $\mathrm{NP}_{\mathrm{o}}$ from 0.0056 \pm 0.0023 to $0.2475 \pm 0.0261(\mathrm{P}<0.05)$ and to $0.8949 \pm$ $0.1573(\mathrm{n}=6, \mathrm{P}<0.05)$ as paired experiments advanced from rest, to PMA addition and finally to the dual application of PMA and $\operatorname{Ins}(1,4,5) \mathrm{P}_{3}$. Cumulatively, these experiments support an important role for PKC and $\mathrm{IP}_{3}$ in the activation of SOCs in PASMCs.

\section{Discussion}

This study is the first to use patch clamp electrophysiology to investigate the role of protein kinases in the modulation of SOCs in rat PASMCs. To briefly summarize, this study observed that PKG and PKA elicited an inhibitory effect on SOC channels when measured at the whole cell and single channel level. Conversely, PKC appears to activate these channels and this augmentation was enhanced by the addition of $\operatorname{Ins}(1,4,5) \mathrm{P}_{3}$ (Figure 7). The findings show that SOCs in PASMCs are 
A
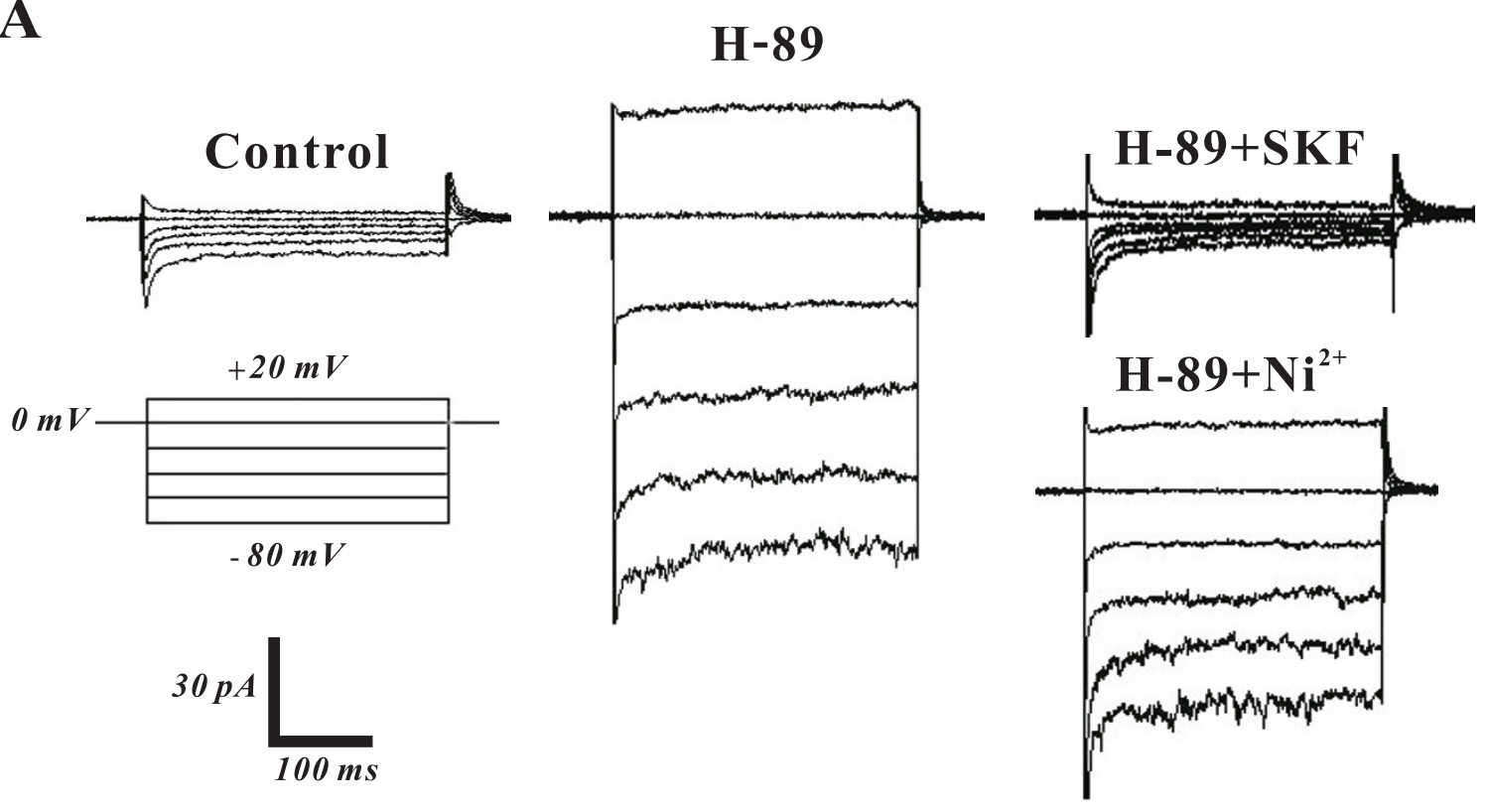

B

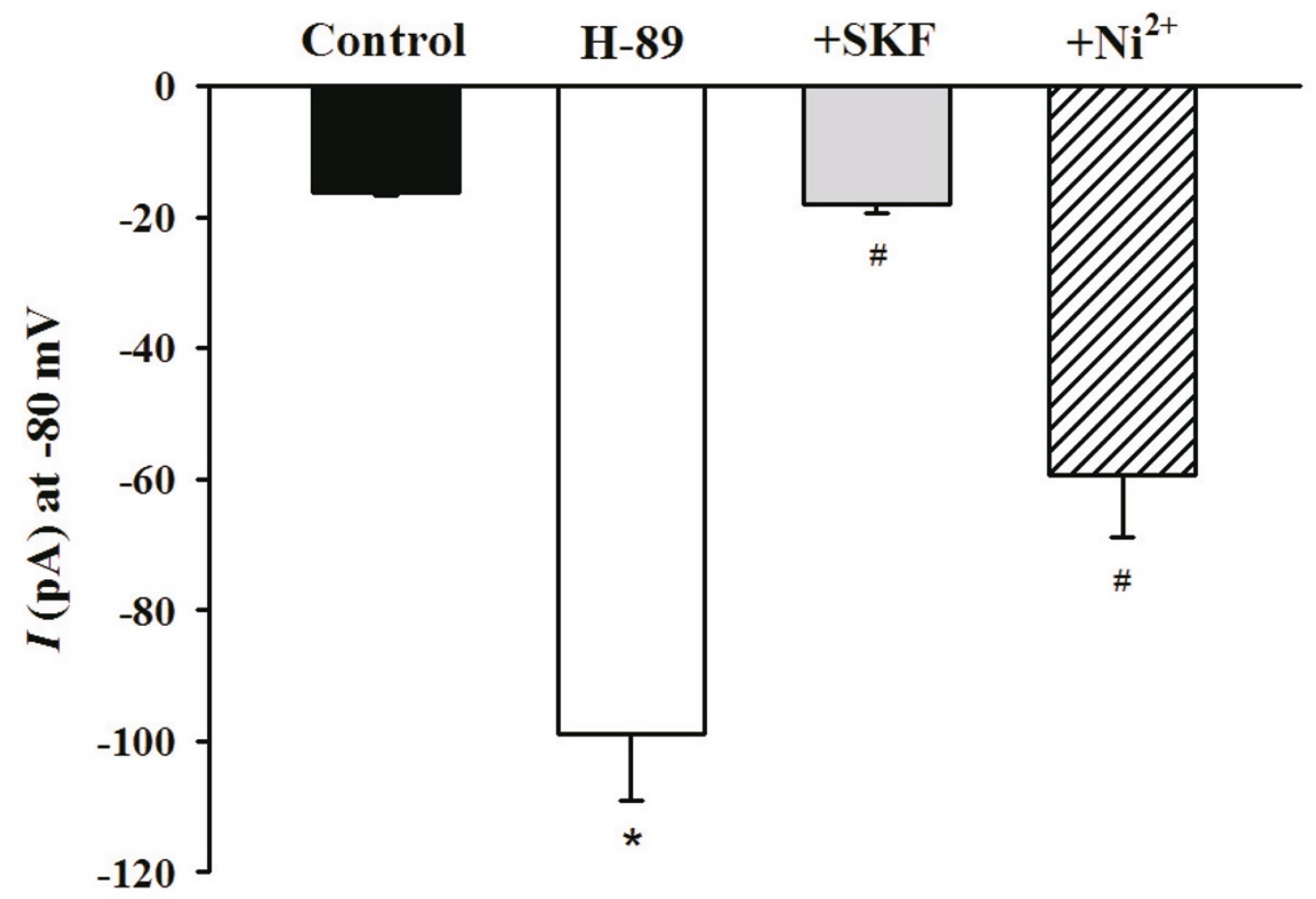

Figure 4 PKA inhibition by H-89 augments SOC whole cell currents. Using whole cell patch clamp electrophysiology, PASMCs were voltage clamped and then periodically exposed to a step protocol (-80 mV to $+20 \mathrm{mV}, 20 \mathrm{mV}$ increments, $300 \mathrm{~ms}$ duration) in the absence and

presence of $10 \mu \mathrm{M} \mathrm{H}-89 \pm 10 \mu \mathrm{M}$ SKF-96365 (SKF) or $0.1 \mathrm{mM} \mathrm{Ni}^{2+}$. A representative trace and summary data can be found in $\mathbf{A} \& \mathbf{B}$, respectively. Data are means $\pm S E, n=6 .{ }^{*}$ and \# denote significant difference from control and $\mathrm{H}-89$, respectively. 


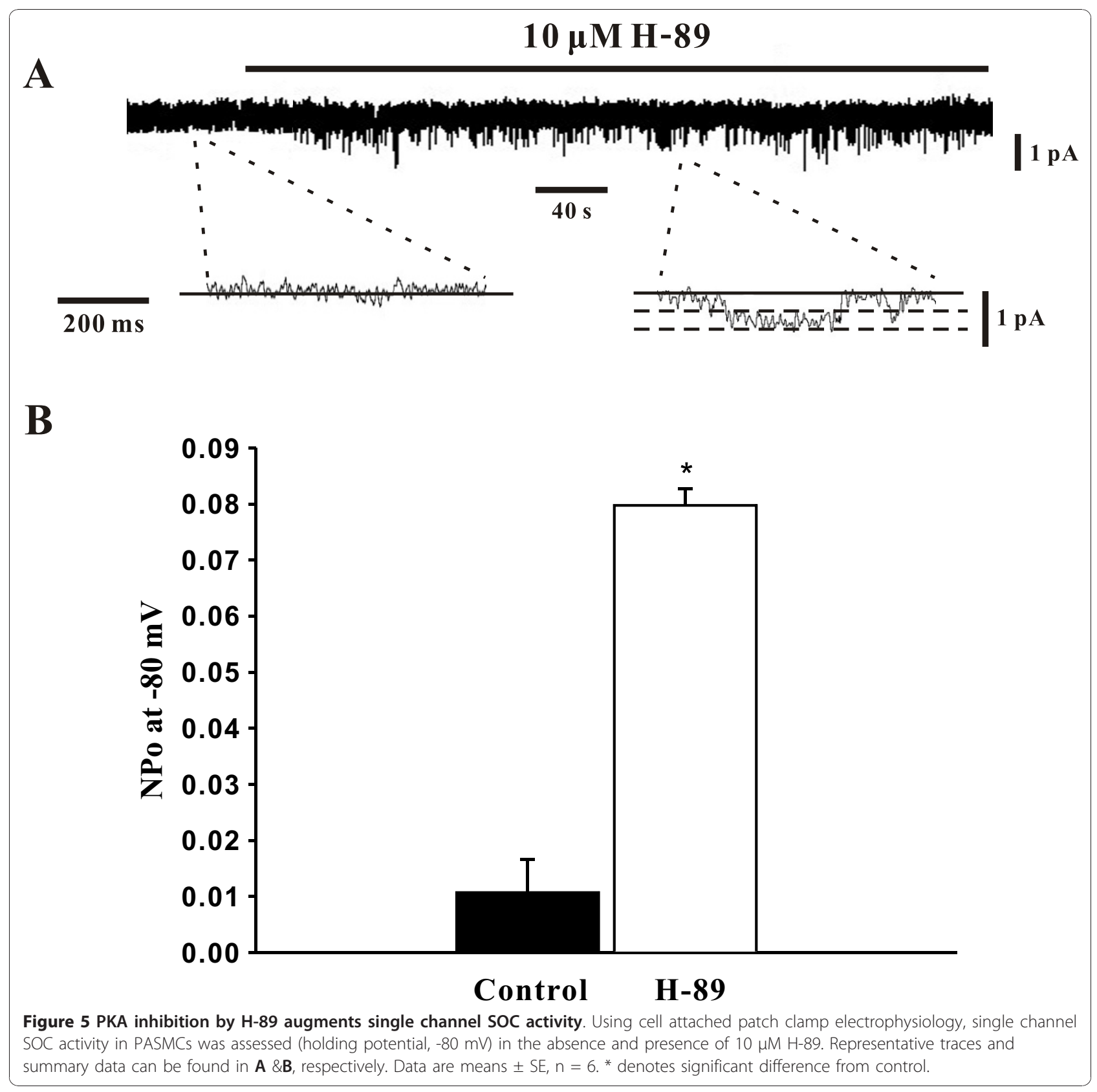

diversely targeted by protein kinases. Such regulation likely plays an important role in setting pulmonary arterial tone under normal and pathophysiological conditions.

Type and character of SOCs in pulmonary artery myocytes

There are three types of SOCs described in vascular smooth muscles. $I_{\mathrm{SOC} 1}$ is the conductance $(\gamma=2-3 \mathrm{pS})$ described in rabbit portal vein myocytes. $I_{\mathrm{SOC} 2}$ is the conductance $(\gamma=3 \mathrm{pS})$ described in aortic smooth muscle. $I_{\mathrm{SOC} 3}$ is the conductance described in mouse anococcygeus muscle due to its estimated conductance of less than $1 \mathrm{pS}$ [4]. Single channel currents induced by CPA have also been recorded in cell-attached patches from cultured human PASMCs, which had a slope conductance of about $5 \mathrm{pS}$ [17]. From the differences in the biophysical properties of SOCs recorded in smooth muscles, it is evident that there are different types of SOCs which probably reflect different molecular identities and possibly physiological functions [4].

SOCs play an important role in controlling $\mathrm{Ca}^{2+}$ influx, arterial tone development and smooth muscle cell growth in the pulmonary vasculature $[6,7]$. While it 


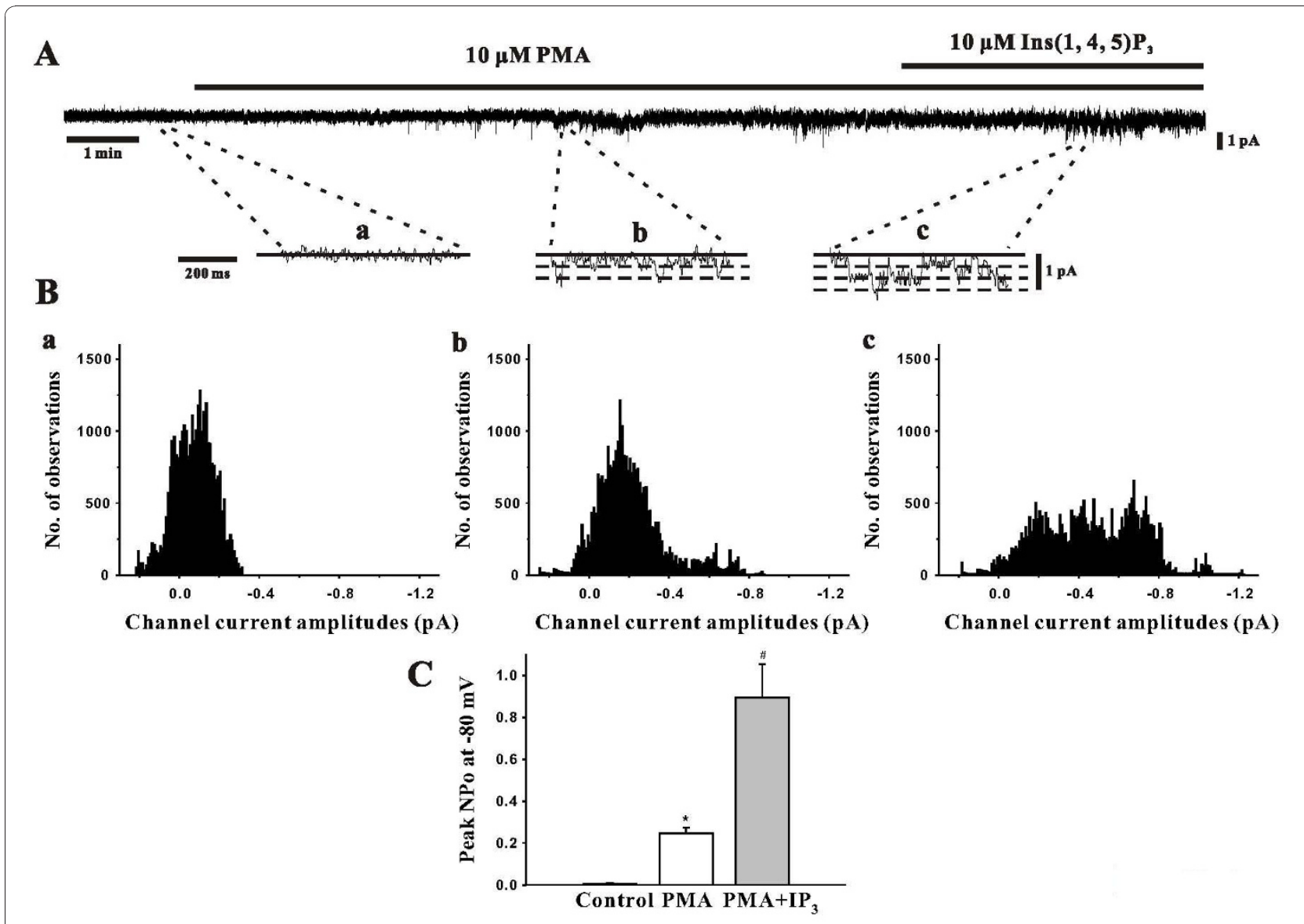

Figure 6 Effects of PKC activation and Ins $(1,4,5) P_{3}$ on single channel SOC activity. Using inside out patch clamp electrophysiology, single channel SOC activity in PASMCs was assessed (holding potential, $-80 \mathrm{mV}$ ) in the absence and presence of $10 \mu \mathrm{M}$ PMA $\pm 10 \mu \mathrm{M} \operatorname{Ins}(1,4,5) \mathrm{P}_{3}$. Representative traces and amplitude histograms of single channel currents $\left(a\right.$, control; $b, P M A ; c$, PMA + Ins $(\mathbf{1}, \mathbf{4}, \mathbf{5}) \mathbf{P}_{\mathbf{3}}$ can be found in $\mathbf{A} \& \mathbf{B}$, respectively. Mean $\mathrm{NP}_{\mathrm{o}}$ data was plotted in $\mathbf{C}$. Data are means $\pm \mathrm{SE}, \mathrm{n}=6 .{ }^{*}$ and \# denote significant difference from control and PMA, respectively.

is commonly agreed that these channels are activated by SR store depletion, their electrical properties do show some degree of variability. For example, the $I-V$ relationship of SOC currents can be both linear in nature or outward rectifying [9]. Their relative permeability for monovalent and divalent cations has also been difficult to precisely define but appears to shift among published studies [17]. In this study, we report that CPA-evoked currents in rat PASMCs display, in essence, a linear $I-V$ relationship at negative potentials and a limited degree of outward rectification at positive potentials. Although relative cation permeability was not directly ascertained, the composition of our recording solutions dictates that at negative potentials, $\mathrm{Na}^{+} / \mathrm{Ca}^{2+}$ influx should dominate the whole cell current where as $\mathrm{Cs}^{+}$efflux will dominate at positive potentials. As such, the SOC channels noted in this investigation share some of the same biophysical characteristics as those previous isolated from rat and human pulmonary arteries $[17,18]$.
Activation of SOCs in pulmonary artery myocytes is regulated by PKG and PKA

The guanylate cyclase-cyclic GMP-protein kinase G signaling pathway plays a pivotal role in several physiological processes including vascular tone development and cell cycle progression. Broadly speaking, studies have shown that activation of this NO-dependent signaling pathway characteristically attenuates SOC activity in smooth muscle [19-21]. This is exemplified by the inhibition of SOCs not only in A7R5 cells [22] but in native smooth muscle cells derived from the mouse anococcygeus and the rat systemic circulation $[4,23,24]$. In HEK293 cells expressing recombinant canonical transient receptor potential isoform 3 (TRPC3), protein kinase G was reported to phosphorylate and inhibit $\mathrm{Ca}^{2+}$ influx through TRPC3 channels, the latter apparently functioning in a store-operated mode [20,25]. On the other hand, cGMP did not affect the inactivation of $\mathrm{Ca}^{2+}$ release-activated $\mathrm{Ca}^{2+}$ current $\left(\mathrm{I}_{\mathrm{CRAC}}\right)$ in $\mathrm{RBL}-1$ cells 


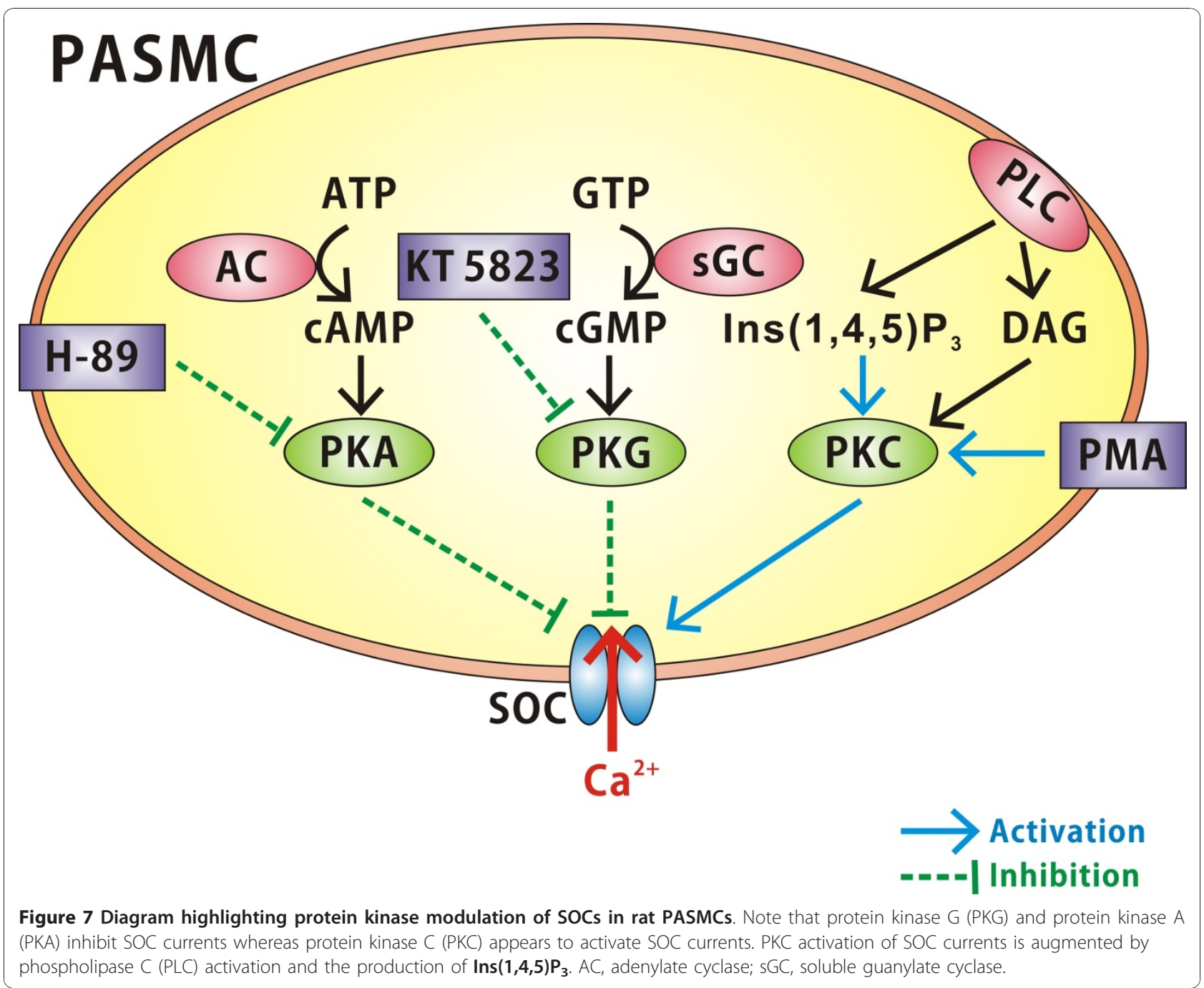

[26], nor did membrane-permeable analogs of cGMP alter store-operated $\mathrm{Ca}^{2+}$ entry (SOCE) in Xenopus oocytes [27], pancreatic acinar cells [28], or T lymphocytes [29]. Regulation of SOCE by cGMP is likely therefore to be cell type specific [25]. In a similar manner, it is thought that the adenylate cyclase-cyclic AMP-PKA signaling pathway relaxes vascular smooth muscle in part due to the inhibition of SOCs [30]. Indeed, in portal vein myocytes, $\beta$-adrenoceptor stimulation attenuates SOC activity whereas PKA inhibitors ( $\mathrm{H}-89$ and KT5720) elicit the reciprocal effect $[31,32]$. With regard to PKA-mediated inhibition of SOCs in portal vein myocytes there is some similarity to data obtained in Xenopus oocytes [27,31]. Petersen and Berridge [27] demonstrated that low concentrations of dibutyryl cAMP (1-10 $\mu \mathrm{M})$ inhibited $\mathrm{Ca}^{2+}$ influx but higher concentrations (1-10 mM) potentiated SOCE. It should be noted that in corneal epithelial cells PKA has also been shown to inhibit an epidermal growth factor- evoked $\mathrm{Ca}^{2+}$ influx pathway, attributed to opening of SOCs [33]. In this study, we extended the idea that both the NO-cGMP-protein kinase G and cAMP-protein kinase A signaling pathways effectively regulate SOCs by demonstrating that PKG and PKA inhibition (KT5823 and $\mathrm{H}-89$, respectively) augment single channel activity in PASMCs. From a physiological perspective, this inhibition would likely raise intracellular calcium $\left(\left[\mathrm{Ca}^{2+}\right]_{\mathrm{i}}\right)$, an event intimately tied to both contraction and proliferation in PASMCs. Such alterations could in turn contribute to the constriction and medial hypertrophy that commonly underlies pulmonary arterial hypertension (PAH).

\section{Activation of SOCs in pulmonary artery myocytes is} regulated by PKC and $\mathrm{IP}_{3}$

Past studies have strongly linked PKC activation to the augmentation of SOC activity in vascular smooth muscle [32]. Particularly noteworthy has been the ability of 
phorbol esters and 1-oleoyl-sn-glycerol (diacylglycerol analogue) to activate and PKC inhibitors to attenuate SOCs $[4,8,34]$. Interestingly, this PKC-induced activation of vascular SOCs appears to be augmented by the production of $\mathrm{IP}_{3}$ and/or the depletion of $\mathrm{PIP}_{2}[2,35]$. Such observations suggest some degree of cooperation among the various signaling events activated by vasoconstrictors via G-protein coupled receptors. In canine pulmonary vein smooth muscle cells, activation or inhibition of PKC was found to have no effect on SOCE [36]; thus, there appears to be considerable diversity in the role of PKC plays in regulating this $\mathrm{Ca}^{2+}$ entry pathway in different cells [34]. Perhaps SOCE pathways differ in different blood vessels. Indeed, smooth muscle cells from mesenteric and coronary arteries have store depletion activated cation channels with distinct properties, although both are activated by PKC [8]. A wide range of properties have been reported for SOCs in different smooth muscle preparations, suggesting that multiple cation channels can be opened by store depletion $[37,38]$. In this study of PASMCs, we observed a similar phenomenon whereby the PMA-induced increase in SOC activity was further enhanced by the application of $\mathrm{IP}_{3}$. Generally speaking, in physiological states this activation would be more important than PKG and PKA inhibition to induce both the contraction and proliferation in PASMCs, which promotes the development of severe PAH.

\section{Limitations}

It is generally agreed that SOCs are relatively difficult to isolate from other conductance channels in the plasma membrane because of a deficiency of highly selective pharmacological agents and the lack of selectively characteristic electrophysiological properties. A previous report [4] demonstrated that cell-attached recording may be an improved method for studying SOCs in smooth muscle, and benefits from the advantage of not disturbing the intracellular milieu. In this study, we initially showed that PKG and PKA inhibition and PKC activation enhance the SOC currents in freshly dispersed rat PASMCs. Nevertheless, over the time course of typical experiments, we cannot exclude the possibility that an induced current of such amplitude is due to a change in 'leak' which might occur, for example, due to myocyte contraction. Accordingly, to further confirm our findings, cell-attached and inside-out configurations were used to measure single channel SOC activity with and without PKG and PKA inhibitors (KT5823 and H-89) and $\mathrm{PKC}$ activator (PMA) and $\mathrm{IP}_{3}$. The data obtained from single channel SOC activity was consistent with those of whole cell SOC currents. However, we still need to interpret our findings cautiously because the supposed opposite effects on SOC channels with activators of PKG and PKA and/or inhibitors of PKC in rat PASMCs remain unresolved. Also, it is not yet clear what upstream and/or downstream signaling molecules are involved in these protein kinase pathways.

\section{Conclusions}

In summary, this study presents evidence that protein kinases play an important role in regulating SOCs in smooth muscles derived from the pulmonary artery. While McElroy et al. [34] previously used $\mathrm{Ca}^{2+}$-imaging technique to show that protein kinases can regulate SOCs in rat PASMCs, this investigation appears to be the first to use patch-clamp electrophysiology to measure similar SOC regulation at the whole cell and single channel level. Given that enhanced SOC activity has been linked to the development of pulmonary arteriopathies, we proposed that protein kinase modulation may provide a means of attenuating the progression of these debilitating disorders.

\section{Abbreviations}

$\left[\mathrm{Ca}^{2+}\right]_{i}$ : intracellular calcium; CCE: capacitative $\mathrm{Ca}^{2+}$ entry; CIF: calcium influx factor; CPA: cyclopiazonic acid; I $\mathrm{CRAC}_{\mathrm{C}} \mathrm{Ca}^{2+}$ release-activated $\mathrm{Ca}^{2+}$ current; ${ }_{\text {iPLA }}$ : $\mathrm{Ca}^{2+}$-independent phospholipase $\mathrm{A}_{2} ; \operatorname{Ins}(1,4,5) \mathrm{P}_{3}$ : inositol 1,4,5triphosphate; PASMC: pulmonary artery smooth muscle cell; PKA: protein kinase A; PKC: protein kinase C; PKG: protein kinase G; PMA: phorbol 12myristate 13-acetate; SERCA: sarco-endoplasmic reticulum $\mathrm{Ca}^{2+}$-ATPase pump; SOC: store-operated channel; SOCE: store-operated $\mathrm{Ca}^{2+}$ entry; TRPC3: canonical transient receptor potential isoform 3

\section{Acknowledgements}

The authors would like to thank Suzanne E. Brett Welsh for her help reading and discussing this manuscript. This study was supported by a grant NSC972320-B-037-006-MY3 to Dr Bin-Nan Wu from the National Science Council, Taiwan. Dr Donald Welsh is supported by the Natural Science and Engineering Research Council of Canada.

\section{Author details}

${ }^{1}$ Department of Pharmacology, School of Medicine, College of Medicine, Kaohsiung Medical University, Kaohsiung, Taiwan. ${ }^{2}$ Department of Pediatrics, School of Medicine, College of Medicine, Kaohsiung Medical University, Division of Pediatric Pulmonology and Cardiology, Kaohsiung Medical University Hospital, Kaohsiung, Taiwan. ${ }^{3}$ Smooth Muscle Research Group and Department of Physiology and Pharmacology, University of Calgary, Calgary, Alberta, Canada.

\section{Authors' contributions}

ISC performed the experiments and drafted the manuscript. ZKD and IJC provided the ideas and participated in the design and coordination of this study, and helped to draft the manuscript. DGW and BNW designed and directed the experiments, interpreted the data and polished the paper to meet the scientific content. All authors read and approved the final manuscript.

\section{Competing interests}

The authors declare that they have no competing interests.

Received: 17 May 2010 Accepted: 6 January 2011

Published: 6 January 2011

\section{References}

1. Salido GM, Sago SO, Rosado JA: TRPC channels and store-operated $\mathrm{Ca}^{2+}$ entry. Biochim Biophys Acta 2008, 1793:223-230. 
2. Liu M, Albert AP, Large WA: Facilitatory effect of $\operatorname{Ins}(1,4,5) \mathrm{P}_{3}$ on storeoperated $\mathrm{Ca}^{2+}$-permeable cation channels in rabbit portal vein myocytes. J Physiol 2005, 566:161-171.

3. Putney JW Jr: A model for receptor-regulated calcium entry. Cell Calcium 1986, 7:1-12

4. Albert AP, Large WA: Store-operated $\mathrm{Ca}^{2+}$-permeable non-selective cation channels in smooth muscle cells. Cell Calcium 2003, 33:345-356.

5. Smani T, Zakharov SI, Csutora P, Leno E, Trepakova ES, Bolotina VM: A novel mechanism for the store-operated calcium influx pathway. Nat Cell Biol 2004, 2:113-120.

6. Landsberg JW, Yuan JX: Calcium and TRP channels in pulmonary vascular smooth muscle cell proliferation. News Physiol Sci 2004, 19:44-50.

7. Lu W, Ran P, Zhang D, Peng G, Li B, Zhong N, Wang J: Sildenafil inhibits chronically hypoxic upregulation of canonical transient receptor potential expression in rat pulmonary arterial smooth muscle. Am $J$ Physiol Cell Physiol 2010, 298:C114-C123.

8. Saleh SN, Albert AP, Peppiatt CM, Large WA: Diverse properties of storeoperated TRPC channels activated by protein kinase $C$ in vascular myocytes. J Physiol 2008, 586:2463-2476.

9. Ng LC, Gurney AM: Store-operated channels mediate $\mathrm{Ca}^{2+}$ influx and contraction in rat pulmonary artery. Circ Res 2001, 89:923-929.

10. Hamill OP, Marty A, Neher E, Sakmann B, Sigworth FJ: Improved patchclamp techniques for high-resolution current recording from cells and cell-free membrane patches. Pflugers Arch 1981, 391:85-100.

11. Luykenaar KD, El-Rahman RA, Walsh MP, Welsh DG: Rho-kinase-mediated suppression of $K_{D R}$ current in cerebral arteries requires an intact actin cytoskeleton. Am J Physiol Heart Circ Physiol 2009, 296:H917-H926.

12. Wu BN, Luykenaar KD, Brayden JE, Giles WR, Corteling RL, Wiehler WB, Welsh DG: Hyposmotic challenge inhibits inward rectifying $\mathrm{K}^{+}$channels in cerebral arterial smooth muscle cells. Am J Physiol Heart Circ Physiol 2007, 292:H1085-H1094.

13. Yu Y, Sweeney M, Zhang S, Platoshyn O, Landsberg J, Rothman A, Yuan JX: PDGF stimulates pulmonary vascular smooth muscle cell proliferation by upregulating TRPC6 expression. Am J Physiol Cell Physiol 2003, 284 C316-C330.

14. Ng LC, McCormack MD, Airey JA, Singer CA, Keller PS, Shen XM, Hume JR: TRPC1 and STIM1 mediate capacitative $\mathrm{Ca}^{2+}$ entry in mouse pulmonary arterial smooth muscle cells. J Physiol 2009, 587:2429-2442.

15. Smith PD, Brett SE, Luykenaar KD, Sandow SL, Marrelli SP, Vigmond EJ, Welsh DG: $K_{\mathbb{R}}$ channels function as electrical amplifiers in rat vascular smooth muscle. J Physiol 2008, 586:1147-1160.

16. Wilson SM, Mason HS, Smith GD, Nicholson N, Johnston L, Janiak R, Hume JR: Comparative capacitative calcium entry mechanisms in canine pulmonary and renal arterial smooth muscle cells. J Physiol 2002, 543:917-931.

17. Golovina VA, Platoshyn O, Bailey CL, Wang J, Limsuwan A, Sweeney M, Rubin $L$, Yuan JX: Upregulated TRP and enhanced capacitative $\mathrm{Ca}^{2+}$ entry in human pulmonary artery myocytes during proliferation. Am J Physiol Heart Circ Physiol 2001, 280:H746-H755.

18. Guibert C, Marthan R, Savineau JP: 5-HT induces an arachidonic acidsensitive calcium influx in rat small intrapulmonary artery. Am J Physiol Lung Cell Mol Physiol 2004, 286:L1228-L1236.

19. Moneer Z, Dyer JL, Taylor CW: Nitric oxide co-ordinates the activities of the capacitative and non-capacitative $\mathrm{Ca}^{2+}$-entry pathways regulated by vasopressin. Biochem J 2003, 370:439-448.

20. Kwan HY, Huang $Y$, Yao $X$ : Regulation of canonical transient receptor potential isoform 3 (TRPC3) channel by protein kinase G. Proc Natl Acad SCi USA 2004, 101:2625-2630.

21. Yao X: TRPC, CGMP-dependent protein kinases and cytosolic $\mathrm{Ca}^{2+}$. Handbook Exp Pharmacol 2007, 179:527-540.

22. Moneer Z, Taylor CW: Reciprocal regulation of capacitative and noncapacitative $\mathrm{Ca}^{2+}$ entry in A7r5 vascular smooth muscle cells: only the letter operates receptor activation. Biochem J 2002, 362:13-21.

23. Wayman CP, McFadzean I, Gibson A, Tucker JF: Two distinct membrane currents activated by cyclopiazonic acid-induced calcium store depletion in single smooth muscle cells of the mouse anococcygeus. $\mathrm{Br} J$ Pharmacol 1996, 117:566-572.

24. Inoue R, Jian Z, Kawarabayashi Y: Mechanosensitive TRP channels in cardiovascular pathophysiology. Pharmacol Ther 2009, 123:371-385.

25. Parekh AB, Putney JW Jr: Store-operated calcium channels. Physiol Rev 2005, 85:757-810.
26. Parekh $A B$, Penner $R$ : Depletion-activated calcium current is inhibited by protein kinase in RBL-2H3 cells. Proc Natl Acad Sci USA 1995, 92:7907-7911.

27. Petersen CC, Berridge MJ: G-protein regulation of capacitative calcium entry may be mediated by protein kinases $A$ and $C$ in Xenopus oocytes. Biochem J 1995, 307:663-668.

28. Gilon P, Obie JF, Bian X, Bird GS, Putney JW Jr: Role of cyclic GMP in the control of capacitative $\mathrm{Ca}^{2+}$ entry in rat pancreatic acinar cells. Biochem J 1995, 311:649-656.

29. Bian X, Bird GS, Putney JW Jr: cGMP is not required for capacitative $\mathrm{Ca}^{2+}$ entry in Jurkat T-lymphocytes. Cell Calcium 1996, 19:351-354

30. Smani T, Domínguez-Rodríguez A, Hmadcha A, Calderón-Sánchez E, Horrillo-Ledesma A, Ordóñez A: Role of $\mathrm{Ca}^{2+}$-independent phospholipase $\mathrm{A}_{2}$ and store-operated pathway in urocortin-induced vasodilatation of rat coronary artery. Circ Res 2007, 101:1194-1203.

31. Liu M, Large WA, Albert AP: Stimulation of $\beta$-adrenoceptors inhibits storeoperated channel currents via a cAMP-dependent protein kinase mechanism in rabbit portal vein myocytes. J Physiol 2005, 562:395-406.

32. Albert AP, Saleh SN, Peppiatt CM, Large WA: Multiple activation mechanisms of store-operated TRPC channels in smooth muscle cells. J Physiol 2007, 583:25-36

33. Yang H, Sun X, Wang Z, Ning G, Zhang F, Kong J, Lu L, Reinach PS: EGF stimulates growth by enhancing capacitative calcium entry in corneal epithelial cell. J Memb Biol 2003, 194:47-58

34. McElroy SP, Drummond RM, Gurney AM: Regulation of store-operated $\mathrm{Ca}^{2}$ ${ }^{+}$entry in pulmonary artery smooth muscle cells. Cell Calcium 2009, 46:99-106.

35. Saleh SN, Albert AP, Large WA: Activation of native TRPC1/C5/C6 channels by endothelin- 1 is mediated by both $\mathrm{PIP}(3)$ and $\mathrm{PIP}(2)$ in rabbit coronary artery myocytes. J Physiol 2009, 587:5361-5375.

36. Shimizu S, Ding X, Murray PA: Intravenous anesthetics inhibit capacitative calcium entry in pulmonary venous smooth muscle cells. Anesthesiology 2006, 104:791-797.

37. Beech DJ, Muraki K, Flemming R: Non-selective cationic channels of smooth muscle and the mammalian homologues of Drosophila TRP. J Physiol 2004, 559:685-706.

38. Leung FP, Yung LM, Yao X, Laher I, Huang Y: Store-operated calcium entry in vascular smooth muscle. Br J Pharmacol 1996, 153:846-857.

doi:10.1186/1423-0127-18-2

Cite this article as: Chen et al:: Protein kinases modulate store-operated channels in pulmonary artery smooth muscle cells. Journal of Biomedical Science 2011 18:2.

\section{Submit your next manuscript to BioMed Central and take full advantage of:}

- Convenient online submission

- Thorough peer review

- No space constraints or color figure charges

- Immediate publication on acceptance

- Inclusion in PubMed, CAS, Scopus and Google Scholar

- Research which is freely available for redistribution

Submit your manuscript at www.biomedcentral.com/submit
C Biomed Central 